Katie Barclay

Intimacy and the life cycle in the marital relationships of the Scottish elite during the long eighteenth century

Womens History Review, 2011; 20(2):189-206

(C) 2011 Taylor \& Francis

This is a Submitted Manuscript of an article published by Taylor \& Francis in Womens History Review, on 26 Mar 2011 available online:

https://doi.org/10.1080/09612025.2011.556318

\title{
PERMISSIONS
}

http://authorservices.taylorandfrancis.com/sharing-your-work/

Author's Original Manuscript (AOM)

This is your original manuscript (often called a "preprint"), and you can share this as much as you like. As a Taylor \& Francis author, you can post your Author's Original Manuscript (AOM) on your departmental or personal website at any point after publication of your article (this includes posting to Facebook, Google groups, and Linkedln, and linking from Twitter). To encourage citation of your work we recommend that you insert a link from your posted AOM to the published article on Taylor \& Francis Online with the following text:

"This is a Submitted Manuscript of an article published by Taylor \& Francis in [JOURNAL TITLE] on [date of publication], available online: http://wwww.tandfonline.com/[Article DOI]."

N.B. Using a real DOI will form a link to the Version of Record on Taylor \& Francis Online.

The AM is defined by the National Information Standards Organization as:

Definition: The version of a journal article that has been accepted for publication in a journal. A second party (the "publisher" - see "Version of Record" below for definition) takes permanent responsibility for the article. Content and layout follow publisher's submission requirements.

1. Acceptance must follow some review process, even if limited to a single decision point about whether to publish or not. We recommend that there should be a link from the Accepted Manuscript to the journal's website that describes its review process.

2. If the Accepted Manuscript (AM) is processed in such a way that the content and layout is unchanged (e.g., by scanning or converting directly into a PDF), this does not alter its status as an AM. This will also apply to "normalized" files where, for example, an author's Word file is automatically processed into some standardized form by the publisher. The content has not changed so this essentially constitutes a shift of format only, and our terms are format neutral.

3. This stage is also known as "Author's Manuscript" by, for example, the NIH, but we believe that the key point is the acceptance of the manuscript by a second party. Elsevier refers to it as "Author's Accepted Manuscript". SHERPA/RoMEO refer to it as "Postprint", but this term is counterintuitive since it implies that it refers to a version that comes after printing.

\section{September 2018}




\title{
Intimacy and the Life-cycle in the Marital Relationships of the Scottish Elite during the Long-Eighteenth Century
}

\author{
Katie Barclay, University of Warwick
}

\begin{abstract}
Traditionally marriage has been treated as one step in the life-cycle, between youth and old age, singleness and widowhood. Yet an approach to the lifecycle that treats marriage as a single step in a person's life is overly simplistic. Many marriages were of considerable longevity during which time couples aged together and power dynamics within the home were frequently renegotiated to reflect changing circumstances. This study shall explore how intimacy developed and changed over the life-cycle of marriage and what this meant for power, through a study of the correspondence of two elite Scottish couples.
\end{abstract}

Traditionally, marriage has been treated as one step in the life-cycle, between youth and old age, singleness and widowhood. During the eighteenth century, marriage marked a change in status from adolescent to adult for most men and women. It was a significant part of the lifecycle, which, it has been argued, marked the time in men's lives when they held the greatest degree of authority and respect. ${ }^{1}$ For women, marriage brought a complex negotiation between the authority they gained as mistress of the household, and perhaps mother of a family, and as subordinate to their husband. ${ }^{2}$ Studies of marriage have given considerable insight into the workings of authority within marriage and how this differed from being single and changed with widowhood. ${ }^{3}$ Yet an approach to the life-cycle that treats marriage as a single step in a person's life is overly simplistic. Many marriages were of considerable longevity during which time couples aged together and power dynamics within the home were frequently renegotiated to reflect changing circumstances. During the course of a marriage, most couples would hope to have children, to develop in their careers, for those of rank- to inherit titles, to age and to gain the influence and authority associated with middle, if not old, age. Family dynamics were constantly altering and shifting as an individual's status changed both in the family and within wider society. Marriage was a dynamic process, not a single step. 
While consideration has been given to the relationship between ageing and authority, little work has been done on what that meant for the couple within marriage. ${ }^{4}$ During this period, women of this social group often married in their mid to late teens (moving into the early-twenties at the end of the century) to men who were on average ten years older. ${ }^{5}$ The young age of women at marriage, in particular, ensured that ageing had a real affect on power dynamics as girls became women and women learned to be wives. Similarly, consideration needs to be given to the 'age' of the marriage, reflecting on how power dynamics developed as trust and confidence in a partner's abilities grew over the course of years. As responsibilities altered, children were born and matured, and men and women's social positions were transformed, the marital relationship inevitably evolved and this had implications for power within the household.

Drawing on the correspondence of the Scottish elites during the long-eighteenth century, this article shall explore the life-cycle of marriages, asking how power dynamics shifted between couples as they aged together. There are a number of ways to approach a study of life-cycles, including how economic resources were used and altered over time, the impact of children on marriage, the effect of wider family on marriage over time, and changing levels of intimacy. All of these factors can be explored to uncover how power was negotiated within marriage and how levels of power changed over the life-cycle. This article will concentrate on a discussion of intimacy as it is frequently equated with democratic personal relationships, reducing, if not removing, power, although it is often difficult to disentangle from the many other aspects of the marital relationship. ${ }^{6}$

Intimacy is difficult to define. Attempts to measure it have looked at a 'couple’s level of closeness, sharing of ideas and values, shared activities, sexuality, knowledge about each other, and acts of affection such as holding hands. ${ }^{7}$ It is also generally thought that intimacy takes time to develop, unlike, perhaps, sexual attraction, and that it is closely related to trust. ${ }^{8}$ 
Modern conceptions of intimacy are related to equality and democracy, with intimacy in personal relationships dissolving power structures that are thought to interfere with closeness and personal development. ${ }^{9}$ In an eighteenth century context, intimacy was not expected to neutralise the careful gender and rank hierarchies that marked polite behaviour, but there was precedence of a democratic intimacy in the rhetoric of classical friendship that was to become increasingly popular over the century. ${ }^{10}$ The applicability of democratic intimacy to marital relationships is particularly contested. While historians, such as Lawrence Stone, pointed to the eighteenth century as a time when a rise in intimacy equalised the relationship between spouses, others, such as Amanda Vickery for England and Keith Brown for Scotland, have shown that intimacy was a central part of the marital relationship long before this period operating within patriarchal family structures. ${ }^{11}$

One reason that the eighteenth century was thought to have seen a change in the marital relationship was the rise of romantic love and a move away from a conception of love based on duty and action. ${ }^{12}$ Romantic love brought with it an elaborate vocabulary of emotional expression that transformed how couples communicated, and it came with broader social changes, such as the rise of the individual, the culture of sensibility, and the emergence of consumerism. ${ }^{13}$ This culminated in changing courtship practices where, at least superficially, individuals began to have more control over choice of partner and love came to be expected before, as well as after, marriage. ${ }^{14}$ But, while love and intimacy are closely related, they are not synonymous. Individuals often use the language of love to indicate that they are in an intimate relationship, but the same language can be drawn on by an unrequited lover whose relationship with his beloved is tenuous and even unwanted.

Intimacy is founded on knowledge of the other's mind and habits and that knowledge is frequently built on time spent together and close physical interaction. In an eighteenth century context, it involved providing, or pretending to provide, access to a 'private' self that 
differentiated itself from a 'public’ persona. Privacy was a growing concern during the period reflected in changing architectural concerns, the removal of servants from 'family spaces', and the creation of the home as a 'haven' from the public world, but this sat uneasily alongside the culture of sensibility's concern with hypocrisy and a belief that the public man should be a reflection of the private. ${ }^{15}$ The tension between a private, intimate self and the potential for exposure, both as a hypocrite and to the public eye, made one party in an intimate relationship vulnerable, while requiring discretion from the other. As a result, it relied on trust, yet intimacy could exist between people where the potential for betrayal was more potent than others, such as between master and servant, and even be an inevitable, but undesirable, consequence of household dynamics. ${ }^{16}$ Intimacy did not remove power hierarchies created by gender and class, but rather operated to complicate power relationships as they were enacted in social practice. Furthermore, intimacy, perhaps unlike love, was not the product of a moment, but developed and altered over the life-cycles of relationships.

The study of intimacy over the life-cycle is difficult to demonstrate without a close reading of the life of particular couples, and for this reason, this article focuses on two case studies the marriage of Sir James Grant and Anna Duff and that of Philadelphia StuartMenteth and John Francis Miller Erskine, Earl of Mar. They are drawn from a wider study of the marital relationships of the Scottish elites between 1650 and 1850 and are used as a vehicle to comment on the experience of intimacy amongst the elites more broadly. ${ }^{17}$ References to other couples in the study support the discussion at various points. The main source of information for this article, and the wider study, is the correspondence of individual couples and their families. It is difficult to select any couple as 'typical' of the social group, but, while the marriages selected each have distinct features, they also highlight broader social trends and experiences. Their letters shall be used to explore broader social changes in how couples addressed each other over the duration of their marriage; in how they made 
requests of each other; in the level of formality of expression; how comfortable they appear to be within the relationship; and in how much trust they placed in each other. It will ask how these changed over the life-cycle of the marriage, what motivated change, and finally discuss what this means for power within marriage.

The Scottish elites during this period were a relatively small, closely connected group, ranging from wealthy, middling sorts to powerful aristocrats. With only a few exceptions, they all had ties to the land, either through ownership or as children of landowners, but most made money from a variety of occupations, from land reclamation to the military, from the professions to trade. When writing their correspondence, they ranged in age from late-teens, when many elite Scottish women married, to old age, and the lengths of their marriages varied from weeks to decades. Their letters were written in a variety of situations, but were in the main between spouses who were absent from each other due to business or family demands. ${ }^{18}$

The average length of marriage was 22.1 years and ranged from a one year marriage, which ended prematurely when the wife died in childbirth, to two marriages that lasted for forty-six years. Despite their longevity and the potential for exploration of the life-cycle, surviving correspondence tends not to reflect the entire life-cycle of a specific couple. Spending time apart, which allowed for the creation of correspondence, appears to have also been part of the life-cycle. Correspondence is rare during the 'honeymoon' period and for many couples tends to cluster over periods that may last years, but do not reflect the entire length of the marriage. Archibald Campbell's letters to his wife, Christina Watson, are spread over a fifteen year period, but the bulk of them were written when he is relatively young and in London, seeking patronage to ensure the publication of a book. ${ }^{19}$ Margaret, Countess of Panmure's correspondence to her husband dates from his exile to France after the 1715 Jacobite Rebellion, and reflects the last eight years of his 65 year life, and 36 year marriage. ${ }^{20}$ 
As a result, it is difficult to recreate the scientifically representative samples of modern sociological research. Having said this, there are a number of marriages, notably of individuals who had multiple estates, sat in parliament and court or had military occupations, which left correspondences that ranged across their much of length, as individuals performed their annual duties away from home. The correspondence of the Duke and Duchess of Hamilton, of Anna and Archibald Grant and the Earl and Countess of Leven are good examples. $^{21}$

Letters are not a simple representation of the past, nor can they allow access to the free expression of the soul. They are a cultural practice, conforming to the social conventions of letter writing and behaviour more generally, and are a collaborative venture, conveying the identity of both reader and writer, both through their use of shared cultural narratives or scripts to communicate meaning and because letters are usually part of a two-way conversation. ${ }^{22}$ In the eighteenth century, the act of letter-writing became a cultural obsession; it was not only a convenient method of communication, but a literary phenomenon. Between 1700 and 1800, over 21,000 items were published with the word 'Letter' or 'Letters' in the title, creating a genre of epistolary literature. ${ }^{23}$ These exempla taught the eighteenth-century letter-writer how to convey proper social status between writer and reader, how to communicate emotion, such as love or sorrow, how to make requests and to give compliments, and how to perform intimacy through the art of the pen. ${ }^{24}$

Different types of letters, such as the love-letter, existed and followed particular rules so that historians can now, if not without some difficulty, categorise letters by type. ${ }^{25}$ Expressing an abstract emotion required shared metaphors that ensured many writers expressed frustration that their loving discourse was 'what any common lover would say., ${ }^{26}$ Yet, the language of letters was subject to fashion, especially with regard to conveying emotion where originality of expression was prized and associated with genuine sentiment. 
Trends in emotional expression were particularly marked in the eighteenth century as the rise of Romanticism created a society that delighted in extravagant displays of emotion, before a wave of scepticism at the end of the century brought an end to the 'tiresome insincerities' that had delighted their forebearers. ${ }^{27}$ These fashions are evident in the letters of the Scottish elite, creating a context for letters written between spouses and giving meaning to the expressions used within them, so that 'I love you' has unique significance at different historical moments. It is also worth noting that not all people follow fashion and couples adapted to changing conventions in language at different paces, so multiple linguistic scripts could exist alongside each other, given meaning by the history of a relationship as well as a broader social context.

The letter is usually written in absence and/or at a distance. It is an attempt by the writer to extend her or his everyday life across time and space to the reader. This distance can allow the writer to say things or express emotions that he or she would not have done in person, while the opposite is also true. How a marriage functioned when performed through correspondence and over distance may have very little in common with how a couple behaved when together. Yet, this is not to say they are entirely removed from experience. Letters give insight into how couples talked to each other, how they expressed love and created intimacy, how they fought, how they negotiated the day-to-day management of the household and, often, the estate or family business. For the period under study, they are perhaps uniquely situated to provide insight into life-cycles, capturing not just a single moment in time, but giving a sense of change over time. This is particularly true of the intimate letter, which for married couples, was often an evolution of the love-letter began in courtship or early marriage. Unlike the love-letter, where the central concern of the writer is to convey emotion and to build a relationship, the intimate letter within marriage reflected time spent together and knowledge of a partnership. It was the love-letter of a more mature 
relationship, where fulfilment of duty, wider friends and family, and day-to-day events mingled with affection.

Sir James Grant of Grant (1738-1811), agricultural improver and politician, married Jean or Jane Duff (d.1805), only daughter and heir of Alexander Duff of Hatton in January 1763. He was twenty-four and she was no more than seventeen. ${ }^{28}$ They had thirteen recorded children over their forty-two year marriage. We know little about how they met, but by the 1760s it was normal for elite Scots to have at least a semblance of free choice within courtship, if within a suitably socially-restricted group and requiring the blessing of parents. ${ }^{29}$ The Grant and Duff families, however, had intermarried regularly in previous generations, and were to continue to intermarry in future generations, highlighting that changing courtship practice did not necessarily mean a break with tradition. James' early letters reflected both the formality and hope of courtship. In 1762, he addressed her as 'My Dear Miss Duff' and described 'the terrible Blank- no letter from My Dear Miss Duff, alas my dear madam do favour me with a few lines, consider what suspence is.' He concluded with the mixture of affection and deference that was conventional during the period, 'I beg leave to subscribe myself with love \& affection your most devoted \& obliged humble servt. ${ }^{\text {,30 }}$

After marriage, his letters became warmer and less formal. He addressed her as 'My dearest Jeanie', which was to remain his sobriquet for her throughout their long marriage. This was a typical address for a spouse after the mid-century, sitting comfortably amongst 'My dearest Betty', 'my dear Clem', and 'my dear John' that were found in other couples' letters. It combined a generic term of affection with a personal pronoun, reflecting the need for Romantic lovers to highlight the personal and peculiar nature of their intimacy, compared to the more generic 'sweetheart', 'dear heart', 'my dearest', 'my comfort', 'my dearest heart' that opened letters in the early part of the century. ${ }^{31}$ The first surviving letters from their marriage date from 1767, when they were four years wed and he was in London attending 
parliament. They contain a level of formality of expression and he makes a concerted effort to write long, expressive letters.

James began a letter from that year:

I have this evening been made happier than I can express, by receiving a number of most pleasing letters from Moy [?]- O my love what is this world without private happiness, public is just a bubble, never so horrible as when enjoy’d [...] poor Menie writes about you in raptures- alas who would not if they knew you.

He used a broader social concern within Scottish society that emphasised the virtues of the private sphere, over the corrupting and vapid public world, to bind himself to his spouse. ${ }^{32}$ James positioned his happiness in the private sphere and distanced himself from the public world, where he was physically located. By doing so, he not only marked himself as the true man of sensibility, but through linking the private sphere with his wife, he located himself alongside her, creating closeness and intimacy over distance. He finished 'adieu my love my life, my soul my all in all my affectionate loving charming wife dearest of all names. ${ }^{33}$ In another letter from 1773, he wrote, 'I am infinitely obliged to you for your kind attention to the distress of the poor people in Urquhart- It was perfectly right to send Duncan- but when does my beloved soul do anything that is wrong'. ${ }^{34}$ His language is typical of the elaborate romantic expression of the period, drawing on broader social conventions, and it operates to create intimacy and to provide reassurance of their emotional connection. ${ }^{35}$

By 1800 and after thirty-seven years of marriage, James’ letters became shorter and less formal. He began 'my dearest Jeanie, I wrote to you that I suspected I should be on another committee I however through favour got my name kept out,' jumping straight from the address to the content of the letter. They discuss news and her coming to visit him and he 
notes, 'do just as your inclination \& prudence directs', before finishing, 'I need not say how happy I shall be or how much I long to see you. At the same time would have you do as you see proper My loved friend your ever affect. Ja: Grant. ${ }^{36}$ James still indicated his longing for his wife, but no longer used such elaborate expression, nor did he feel a need to predicate his news with elaborate reassurances of his affection. He even abbreviated his final farewell to 'your ever affect.' After a long marriage, intimacy no longer needed to be enacted through writing; it was taken for granted. An abbreviated subscript was not a mark of disrespect, but a quick reminder of what was already known by the reader. It also reflected changing social values at the end of the eighteenth century that viewed elaborate emotional expression with cynicism, questioning its sincerity. ${ }^{37}$ This allowed James to use a short-hand for emotional expression and have it signify intimacy, not disregard. Yet even in the nineteenth century when the flowery language of mid-eighteenth century romance had declined, such an abbreviation could not be used in the first flush of love.

James' choice within this letter to remind his wife of his longing and affection was directly related to the discussion of their meeting, and was not typical of much of his letters from this period that simply passed on news, gossip and offered his thoughts on the household management and the estate. He was keen to reassure his wife that his lack of insistence on her visiting did not reflect an absence of affection or disinterest on his part, but simple pragmatics. Similarly, the minister Archibald Lawrie wrote to his wife in 1797 that:

I saw neither you nor my sweet infants, I felt strange, strange indeed \& off I set to Loudon to my bed I have been close at home since Friday attending my workers but the nights frighten me to death. It is a sad thing for one to be alone. ${ }^{38}$ 
This linking of love and longing to discussions of absence is a very common motif in correspondence across the century and reflects that even in marriages where separation was common, it was always a place of tension. Time apart is treated as an aberration within the marital relationships of the Scottish elites, who prized physical proximity, and caused couples to express concern and anxiety, which in turn was met with reassurance that it did not reflect absence of affection. Where this convention was not observed, it was almost always intentional and was a clear message to a spouse that their marriage was in trouble. ${ }^{39}$

Despite its relationship with increased familiarity over time, intimacy was not directly linked to equality or a democratisation of the marital relationship in the way modern intimacy is understood. Jane's letters to James, which mostly date towards the end of their marriage, highlight the subordination expected of wives within the period and the extent to which this informed couples understanding of marriage. She addressed her husband as 'My very dear Sir James' or 'My Dearest Sir James.' Internally, she ended requests with the words, 'Sire'. This is unusually formal for the period, as most wives would have dropped the 'Sir', although not atypical of marriages in the early part of the century. Jane also took her husband's name on marriage, which, in the 1760s, was a relatively new, and far from ubiquitous, trend among Scottish elite women. This may have reflected her husband's English education and a desire to conform to a British, rather than Scottish identity (also reflected in the formal styling of her name as Jane, despite her being commonly referred to as Jean), but its significance for power is less clear. ${ }^{40}$ The widespread adoption of husband's names by Scottish elite women in the latter part of the eighteenth century reflected the increasing autonomy of the conjugal unit from the wider family and a desire to create a separate nuclear family that was distinct from broader kin networks. This spoke to the intensifying of intimacy within the nuclear family, at the expense of wider familial and non-familial relationships; it was a trade-off that 
reduced women's power within kin networks, but perhaps heightened woman's social power as the heart of the domestic sphere. ${ }^{41}$

Jane's surviving letters are usually brief and feel brisk, but affectionate. She included lots of details on life at home, tenants, new babies in the family, visitors, what the mail says (which is frequently her motivation for writing), as well as details of his regiment, court martials and new recruits. Partly because they date from the latter part of their marriage, but also reflecting social norms that restricted female expression of emotion, there were few lengthy or elaborate expositions of love. ${ }^{42}$ Jane usually finished, 'your affectionate and faithfull friend' or 'I most affectionately truly yours J Grant.'43 Other eighteenth century women finished their letters to their husbands in a similar manner, adopting a manner of subscription that had been common amongst men in the latter part of the previous century, but that had now been discarded. ${ }^{44}$ Elizabeth Hay subscribed her letters 'how affectionately I am yours', and Mary Campbell ended hers 'my deare yours very affactionetly’. ${ }^{45}$

From the first words, Jane’s letters highlighted her social subordination to her husband, allowing her greater freedom within the text to express opinion and even consider herself a friend, a term that until the 1740s usually denoted parity of social position, and unusual in spouses' letters before debates on platonic friendship became fashionable around the mid-century. ${ }^{46}$ Through setting the parameter of their relationship at the outset, she signified the deference with which she approached her spouse. That Jane and James were not equal within marriage did not remove the intimacy of their relationship. Jane felt free to offer her husband's estate management skills to 'the Duchess' without asking his permission, which later distressed him as 'he had hardly time to manage his own', but his concession to 'do everything in his power' also suggested that she had not misjudged the situation. ${ }^{47}$ She knew her husband well enough to make decisions without consultation and that her word bound James to act indicated wider cultural expectations that wives could and did speak for 
husbands. A wife's right to manage the household economy was given backing under Scottish law (a security for nervous creditors), which tacitly reinforced this expectation. ${ }^{48}$ Intimacy was created and, perhaps even enforced, within a framework of accepted cultural expectations for marriage.

Intimacy was not just expressed through terms of endearment, but shown by levels of trust. Trust developed over time, but it had different facets and couples could trust in multiple ways. Men, who were frequently absent from home, often had to learn to trust their wives to manage money and the household relatively quickly. Unfortunately, we do not have evidence for the first three years, where problems may have arisen, especially given Jane's youth. However, we know that in the first years of marriage, the couple spent a lot of time in his family home, where his parent's lived and which he eventually inherited. Throughout her life, Jane was also in constant correspondence with her mother, who freely gave advice and even offered a home when they faced seemingly insurmountable debts (this was politely declined). ${ }^{49}$

Living with an older generation was a common experience for many young brides, particularly the wives of heirs who were waiting to inherit, and in many ways, it was this expectation that allowed the Scottish elite to marry at young age. Young brides were advised to conform not only to their husband, but their husband's families. Elizabeth Clerk was told by her father on the advent of her marriage to:

take a great deal of pain to please \& oblige all your neighbours bot especially your godfather his lady \& bairns [her in-laws] \& be over a good instrument of promoting love peace \& concord amongst them [...] with advice of your husband. ${ }^{50}$ 
Fifteen year-old Margaret Strowan was given very similar advice by her father on her marriage in 1755, while Francis Grant told his son, Archibald, that he should select a bride that would get on with her mother-in-law as: 'I can love or respect none, who does not so toward my wife, who so well deserves it. ${ }^{51}$ Husbands' trust in their wives was often built on the knowledge that they not only married a woman, but a family network that had an interest in their success.

Trust and intimacy within eighteenth-century society was not created between couples within a vacuum, but was helped, and sometimes hindered, by friends and family. Yet, as the eighteenth century advanced, this ideal was at tension with greater expectations of privacy for the conjugal unit, marked by the reinvention of the honeymoon as a time for the couple to be alone, rather than in the company of family. ${ }^{52}$ Furthermore, not all family members had equal access to family support with younger children frequently living independently of their parents after marriage. Despite these tensions, age at marriage for elite Scottish women only rose by two years from 18.8 to 20.4 between 1650 and $1850 .{ }^{53}$ This may reflect that the ideals of privacy and separation from family were hard to apply in practice. Having said this, the lack of correspondence that survives for the initial years of most marriages during the period may indicate that spouses made an effort to spend time together, perhaps reflecting on the need for physical proximity in the development of trust and intimacy.

By the time James inherited in 1773, Jane managed the household and occasionally their estates in his absence. ${ }^{54}$ Some marriages, such as that of Anna and Archibald Grant of Monymusk, experienced problems establishing trust in this area, but James and Jane seemed to have found equilibrium within the first few years. ${ }^{55}$ He often asked her advice and even sent her letters of importance to read over before he posted them. ${ }^{56}$ Jane was periodically sent explicit instructions, especially when people needed paid, but the infrequency of such directions is indicative of the level of control she had. ${ }^{57}$ Furthermore, James realised that a 
display of trust was an important part of maintaining a good relationship with his wife. When she was visiting friends in 1774, he sent her money to 'tip' the staff, saying she should 'leave triumphantly'. He indicated how much she should give to each person, but concluded that he left it to her discretion and if she paid more, he would make up the difference. ${ }^{58}$ The marital economy, however, was only one area in which trust could be exercised.

Early in marriage, James found himself jealous and later apologised for his doubt:

It is always the case my dearest soul, where there is ardent love there will be a thousand imaginary uneasinesses, which have no foundation but in the brain of the person affected by it, \& I believe it is often the case with me, for why should I think that so dear and near connection as you whould mistake one another. Yet jeanie you must forgive me I love and adore you \& next to you no thing can be more dear to me than my sisters however it was always folly \& I am sure would never occur to any but my anxious foolish brain.

My dear heart your letters make me happier than I can express wrote with such ease and warmth of sentiment as sufficiently the [illegible- ink spill] what the dear mind feels. ${ }^{59}$

The letter is undated and, unfortunately, evidence of the context in which it was written has not survived, although the reference to his sister suggests that his family may have been involved. It is clear that James questioned his wife’s behaviour, and later regretted impugning her character. Like in his early letters, he used expressions of love to reinforce and enact trust and intimacy over distance, but added a sprinkling of flattery, of her writing style, to sweeten his apology. While this letter is undated, it is likely from their early marriage. Older women were both less likely to commit, or to be accused of (without very good reason), a social faux 
pas that opened them to criticism by their spouse. Husbands were also more confident in their wives as marriages progressed and wives expected a greater degree of respect, having earned it through years of faithful service. Furthermore, as wives passed the age of child-bearing, the threat of illegitimacy that infidelity posed was less pressing on the minds of men. ${ }^{60}$

Such an insult to a woman's character may have given her momentary power over her husband as he sought to rectify his fault, but James quickly neutralised any opportunity for Jane to use this to her advantage. In the following paragraph, he discussed his mother-inlaw's visit and requested to borrow her horse to ensure he returned home 'immediately.' In doing so, he assumed his wife accepted his apology, which was in itself a mark of intimacy and trust in the strength of his marriage. But, by combining an apology and a request within the same letter, he made it almost impossible for his wife not to move past this mistake. His wife could have ignored his request, but, in doing so, she escalated the incident and more significantly disobeyed her husband, placing her in the wrong. A relationship negotiated by post and over distance could not afford the time to voice every irritation or injury, especially at the expense of the fulfilment of duty.

A woman's subordination in eighteenth-century Scotland was not expected to preclude her from expressing hurt feelings or even anger, but her responsibility to her husband and obligation to obey was expected to take precedence. Placing duty ahead of passion was a central tenet of life for women and men alike. As another husband, John Blackadder, noted to his wife, Anne, at the beginning of the century, 'my inclination would lead me to have you always near me, [...] But you must consider, it is not by inclinations we are to be held but by duty'. ${ }^{61}$ It was possible to be dutiful in action, but still resentful and angry at a spouse, and some wives managed to negotiate this balance to great effect. Yet, such power-plays demanded considerable effort and were more common in troubled 
marriages than those where spouses desired a more harmonious marital path. Intimacy and power were complexly combined in marital negotiations.

While not without the occasional squabble, the Grants had a long and happy marriage with relatively few quarrels, at least when apart and corresponding. In contrast, the marriage of Philadelphia Stuart-Menteth (d.1853) and John Francis Millar Erskine, $26^{\text {th }}$ and $9^{\text {th }}$ Earl of Mar and Kellie (1795-1866), was conflict-ridden. Philadelphia was the daughter of Sir Charles Stuart-Menteth of Closeburn, and John was the heir to the premier Earldom in Scotland. They married in 1827 and had no children. The Erskine's had lost their titles and estates during the 1715 Jacobite rebellion and the attainder was only lifted during John's father's lifetime. Despite attempts by family members to salvage the estates, the bulk had been sold in the eighteenth century. John inherited a large house and a small estate. They lived in the manner of the elite, and were active patrons in the local community, but they were not as wealthy as their rank and historical significance implied, and financial worries plagued them. The Erskine's was an unhappy marriage and in 1829, Philadelphia temporarily left her husband. In 1830, their separation was formalised and John agreed to pay alimony. They remained apart for the next two years, although evidence suggests they were briefly reconciled in 1832, before separating again. Correspondence is missing for later in their lives, but her role on the estate suggests that, at the very least, they came to a working arrangement, and friendly correspondence on estate business exists from the 1850s.

Despite their estrangement, the couple corresponded regularly, negotiating intimacy and power in a very different context to that of the Grants, but not one that was unique to the social group. Private separation was reasonably common amongst eighteenth-century elite Scots, who viewed it as a more socially-acceptable option than judicial separation or divorce, both available in Scotland from the Reformation, if on restricted grounds. ${ }^{62}$ While separation ends, at least temporarily, a marriage, it does not always end an intimate relationship. 
Couples that were held together by ties of children, alimony payments, wider kin, and occasionally the desire to hide marriage breakdown from a censorious world, ensured that relationships continued. For some couples, like John's great-grandparents Lord and Lady Grange, a formal separation did not stop further deterioration of their relationship. Lord Grange resorted to having his wife kidnapped and removed to St Kilda to finally destroy their marital tie. ${ }^{63}$ For others, like the Erskines, who never divorced, separation prevented them from establishing new legitimate relationships. Although at least one abandoned Scottish woman, the novelist Mary Leslie, daughter of the $5^{\text {th }}$ Earl of Leven, cohabited with her new partner, George Robinson Hamilton, even they moved beyond the reproach of the Scottish community to France for part of their life. ${ }^{64}$ Intimacy was not ended by choice; knowledge of a partner and the close links created by marriage were not dissolved with the stroke of pen.

Like other early nineteenth-century elites, the Erskine’s believed that they married for love. Although evidence for their early courtship has not survived, it is likely their parents introduced them to a suitably socially restricted group and allowed them a degree of choice. Yet, marriage for love was not without economic implications, and Philadelphia's first surviving letters discussed arrangements for marriage, including the all-important settlement. Like the rest of her class and generation, Philadelphia distanced herself from the vulgar question of money, assuring 'My dearest John' that 'money is no consideration to me [...] I want no other settlement than what my father has made,' although she then discussed in detail their future financial arrangements, signing herself, 'yours most sincerely, P. StuartMenteth' ${ }^{65}$ In the first month of marriage, to signify the change in their relationship, John became 'My dearest husband', and she later alternated between the two addresses throughout their marriage, even after separation. She ended her correspondence 'your affectionate wife, P. Erskine.' In early marriage, John addressed her as 'My dear Philadelphia' and signed himself 'your sincerely affectionate husband, Erskine,' but after their separation, he shortened 
her address to 'Dear Philadelphia.' Depending on whether he was making a request or expressing anger and annoyance, his signed his letters 'Believe me my dear Philadelphia your affectionate husband Mar' or 'yours truly Mar. ${ }^{\text {'66 }}$ Far from being a simple convention, their choice of address over the course of their marriage reflected the negotiation of intimacy and power within their relationship.

From early marriage, John was extremely concerned with Philadelphia’s spending, intervening in her household management and constantly questioning her actions. He became increasingly convinced that she was trying to undermine his authority and she used this to her advantage to manipulate him. This level of interference in the household was unacceptable to Philadelphia on a personal level as it reflected a lack of trust, and it was atypical of husbands of the period. John was paranoid and often erratic throughout his life. He believed that his family members, including his wife, and employees were trying to ruin him and his social reputation. On one occasion, John appeared to have considered the course of his infamous great-grandfather and inquired into having his wife 'removed' to the continent. ${ }^{67}$ His wife discovered his plan and he wrote assuring her that he had no intention of putting her under the care of a Frenchwoman. ${ }^{68}$ He may have suffered from mental ill-health and Philadelphia appeared to have informed him that this was the opinion of his family. His Uncle had to write an apologetic letter, denying that he thought the Earl should 'be shut up for life' ${ }^{69}$

In 1829, Philadelphia's frustration with her marriage caused her to leave and take a summerhouse by the sea 'for her health'. When her husband asked her to return, she wrote:

I thought it was quite understood between us as to the nature of my dejou not that it was from any quarrel but purely that it was by mutual agreement that I was to make trial of this mode of life for a short time; and that I was to apply to you for any money I wanted to defray expenses here. ${ }^{70}$ 
Philadelphia assured him that she would be economical and that she was not being funded by her father, highlighting John's concern with parental interference within their marriage. In a letter that discussed absence, she informed him that she had 'no separate interest from my husband,' but noticeably did not reassure him of her affection. She explicitly continued this narrative throughout 1829, and to an extent throughout the remainder of her marriage, refusing to return, but distancing herself from any imputation of disobedience by feigning miscommunication. Her choice to refer to her husband as 'My dearest John' and to sign herself as 'your affectionate wife' was part of an attempt to disassociate herself from imputations of wrong-doing and to appease her husband. In an early nineteenth century context, Philadelphia was in the wrong; she removed John of his legal right to her person and deprived him of the social and economic benefits of her company. An understanding of emotional abuse was only in its infancy, and Philadelphia lacked the vocabulary to justify her behaviour and would have received little sympathy if she could. ${ }^{71}$ Philadelphia's story not only allowed her to absent herself from her husband, but enabled her to construct a narrative of self, where she was not a failed wife, but an ill woman, similarly to some Victorian spinsters. ${ }^{72}$ Her need to maintain that fiction ensured that she was always dearest John's affectionate wife.

In contrast, John's reaction varies across the life-cycle of the marriage. In the letters that survive from 1829, he seemed content to engage with his wife's narrative of events, playing her illness against his own. He wrote to her soon after she had left:

Dear Philadelphia, I am dying; surely you will not refuse to come and see me. The chambermaid will tell you I am not outrageous but weak: and have not long to live, if I am to meet with no kindness. Why do you put others between you and me when you 
might get anything by speaking to me yourself. I earnestly hope you will differently [sic]; why will you not even let me try. Believe me my dear Philadelphia your affectionate husband Mar. ps I know nothing of what has been transacted or offered one way or another today; but believe me I am anxious to act quite rightly if you will come down here on receiving this. Perhaps I may not long have an opportunity if you refuse me this. ${ }^{73}$

If Philadelphia wished to distance herself from any imputation of wrong-doing, John was willing to raise the stakes. What dutiful wife, even when ill, would refuse to return to the bedside of her dying husband, especially one offering a deathbed reconciliation? Whether she came to visit is unknown, but Philadelphia did not return home on a permanent basis, writing from her summerhouse the following week. Later in the year, John attempted to flatter his wife into returning, commenting 'I cannot say I have been displeased with your conduct since you left this, in the contrary I thought many things praiseworthy and meant to have told you of them. I think you had better come down here, immediately on receiving this. ${ }^{, 74}$

After three years absence, a separation settlement and an alimony agreement, John's mood was not so forgiving. In 1832, he wrote an erratic letter that displayed both anger and his suspicious nature:

As I know on no other way of obviating the insolences and nonsence with which you continually assail me att dinner and att other times and which seems so congenial to your disposition that any hopes of amendment or discontinuation of such detestable behaviour and conduct have always been speedily frustrated. [...] In this way you will have an opportunity of giving these things at my expense to others; in order that they may be insolent to me. ${ }^{75}$ 
John's patience had worn out, although as the letter indicated their relationship had developed to the point that they now saw each other. He believed her behaviour no longer justified her self-presentation as an obedient wife and this entitled him to vent his rage and frustration. His right to express anger was predicated on his authority as a husband over his wife. It was her dereliction of duty and, even more significantly, his belief that this was evident to a wider audience, impacting on his social reputation, which provoked him to speak.

The breakdown of the Erskine's marriage came shortly after the Queen Caroline Affair, where the centrality of familial leadership to masculine identity was reinforced in widespread criticisms of George IV's marital failings. The ability of men to manage their finances and to provide for their families was a central part of this discourse and, while financial probity had long been an important part of masculinity, it was becoming particularly cogent in an early nineteenth century context where domestic or private virtue was at the core of the public man. ${ }^{76}$ John's anger was not simply based on the internal affairs of the heart. That he held authority over his wife, and that she was expected to mould herself to him, allowed him to express a wider range of reactions without dispossessing himself of the role of the wronged husband. Whatever his social power however, he ultimately could not make his wife return home and remain within the boundaries of acceptable behaviour, which was reflected in the range and desperation of the strategies he employed.

While this was a story of marital breakdown, how intimacy and power was negotiated over the life-cycle was not unique. The Erskine's story contained many of the same elements as that of the Grants. John was concerned with physical proximity and Philadelphia's absence was a source of stress, both on a personal level and for the message it gave to wider society. They disputed the role her father should play in their lives, indicating the place of family in creating or disrupting intimacy. The manner in which they riled and manipulated each other, 
and in which they used the family network in their power-plays, highlighted the extent to which they were intimate, with a keen understanding of each other's psyche; information learned within the first years of marriage. Furthermore, while affection may have waned over time, their knowledge of each other did not. Where their marriage failed was an inability to trust. John did not trust his wife's financial management, and later her loyalty to his interest, and she appeared not to trust anything he said, whether that was declarations of ill-health or flattery at her behaviour. Such distrust may have grown from experience over the course of their marriage. Yet, while we shall not know the extent to which they reconciled in later years, they appeared to have developed a working relationship, suggesting that trust could be rebuilt over time, and that marital breakdown did not end a marriage. Throughout their marriage, the privileges that patriarchal society granted to the husband ensured that John's authority and the demands he made on his wife were socially legitimate, but intimacy gave Philadelphia tools to undermine his authority and to negotiate the terms of their marriage. Intimacy in the long eighteenth century was not an equalising force, but it could be used to complicate power relationships.

A life-cycle model that sees marriage as a single step in the lives of individuals simplifies the complex and evolving experience of a marital relationship that could last a significant part of a person's life. Over time, couples negotiated and renegotiated the dynamics of their relationship, learning from increased knowledge of each other's personalities and reacting to changes in their family and circumstances and to society more broadly. The shape of the marital life-cycle was to a large extent determined by individuals and their ability or not to maintain a working relationship. Yet, it was informed by its historical context, with wider culture determining when couples married, what their role was within marriage, how often they were apart, how they communicated with each other and understood that interaction. It influenced what factors shaped a marriage, whether that was 
the right, or not, to express emotion, or the place of wider family within a relationship. The historical context ensured that the life-cycle was not completely unique to individuals, and that even something as personal and emotionally significant as intimacy was culturally constructed. More work now needs to be done on how other facets of marriage developed over the life-course, how they interplayed with intimacy, and what that meant for power.

${ }^{1}$ Elizabeth Foyster (2001) Parenting was for Life, not just for Childhood: the role of parents in the married lives of their children in early modern England, History, 86, pp. 313-327; Anthony Fletcher (1995) Gender, Sex and Subordination in England 1500-1800 (London: Yale University Press), p. 89.

${ }^{2}$ For example Lynn Abrams (2002) The Making of Modern Woman (Harlow: Longman), pp. 69.

${ }^{3}$ There is a large literature on authority and marriage. Some recent examples include: Joanne Bailey (2003) Unquiet Lives: Marriage and Marriage Breakdown in England, 1660-1800 (Cambridge: Cambridge University Press); Elizabeth Foyster (2005) Marital Violence: an English Family History, 1660-1857 (Cambridge: Cambridge University Press); Julie Hardwick (1998) The Practice of Patriarchy: Gender and the politics of household authority in early modern France (University Park: Penn. State University Press); Bernard Capp (2003) When Gossips Meet: women, family, and neighbourhood in early modern England (Oxford: Oxford University Press). Studies of singleness and widowhood include: Sandra Cavello and Lyndon Warner (Eds.) (1999) Widowhood in Medieval and Early Modern Europe (London: Longman); Julie Hardwick (1992) Widowhood and Patriarchy in Seventeenth Century France, Journal of Social History, 26, pp.133-148; Christine Peters (1997) Single Women in Early Modern England: attitudes and expectations, Continuity and Change, 12, pp. 325-345; Pamela Sharpe (1999) Dealing with Love: the ambiguous 
independence of the single woman in early modern England, Gender and History, 11, pp. 209-232; Amy Froide (2005) Never Married: Singlewomen in Early Modern England (Oxford: Oxford University Press).

${ }^{4}$ Keith Thomas (1976) Age and Authority in Early Modern England, Proceedings of the British Academy, 62, pp. 205-548; Ilana Krausman Ben-Amos (1994) Adolescence \& Youth in Early Modern England (London: Yale University Press), pp. 208-235.

${ }^{5}$ Katie Barclay (2007) I Rest Your Loving, Obedient Wife: marital relationships in Scotland, 1650-1850, Unpublished Ph.D. Thesis, University of Glasgow, pp. 120-123.

6 For a discussion of intimacy as democracy see: Anthony Giddens (1992) The Transformation of Intimacy: Sexuality, love and eroticism in modern societies (Cambridge: Polity Press).

7 Shawn Patrick, James Sells, Fran Giordano and Toni Tollerud (2007) Intimacy, Differentiation and Personality Variables as Predictors of Marital Satisfaction, The Family Journal, 15, p. 360.

${ }^{8}$ Whether trust is 'part' of intimacy or a related, but independent, concept is a topic of debate: K.J. Prager (1997) The Psychology of Intimacy (New York: Guildford Press), p. 16.

${ }^{9}$ Giddens, Transformation of Intimacy, p. 189.

10 For further discussion see: Helen Berry (2005) Lawful Kisses? Sexual Ambiguity and Platonic Friendship in England, 1660-1720, in Karen Harvey (Ed.) The Kiss in History (Manchester: Manchester U.P.), pp. 62-79; Rosalind Carr (2008) Gender, National Identity and Political Agency in Eighteenth-Century Scotland, Unpublished Ph.D. Thesis, University of Glasgow, pp. 176-238.

${ }^{11}$ Lawrence Stone (1990) The Family, Sex and Marriage in England 1500-1800 (London: Penguin), p.210; Amanda Vickery (1998) The Gentleman's Daughter: women's lives in Georgian England (London: Yale U.P.), p. 40; Keith Brown (2000) Noble Society in 
Scotland: wealth, family and culture from Reformation to Revolution (Edinburgh; Edinburgh U.P.), p. 155.

${ }^{12}$ Niklas Luhmann (1986) Love as Passion: the codification of intimacy (Cambridge: Polity Press); Irving Singer (1984) The Nature of Love 2: courtly and romantic (Chicago: Chicago U.P.).

${ }^{13}$ For an extended discussion: G.J. Barker-Benfield (1992) The Culture of Sensibility: sex and society in eighteenth-century Britain, (London: Chicago U.P.).

${ }^{14}$ Stone, The Family, pp. 270-391; Barclay, 'Marital Relationships’, pp. 130-163.

15 John Dwyer (1987) Virtuous Discourse: sensibility and community in eighteenth century Scotland (Edinbugh: John Donald), pp. 95-116; Patricia Spacks (2003) Privacy: concealing the eighteenth century self (London: University of Chicago Press), pp. 1-26.

${ }^{16}$ An example of the complexity of emotion in master/servant relationships: Marko Lamberg (2008) Suspicion, Rivalry and Care: mistresses and maidservants in early modern Stockholm, in Susan Broomhall (Ed.) Emotions in the Household, 1200-1900 (Houndmills: Palgrave Macmillan), pp. 170-184.

${ }^{17}$ For the larger study see: Barclay, 'Marital Relationships,'

${ }^{18}$ For a longer discussion, see Barclay, 'Marital Relationships,’ pp. 105-129.

${ }^{19}$ National Archives of Scotland [NAS] GD461/14 Correspondence of Archibald Campbell and Christina Watson, 1723-1742.

${ }^{20}$ NAS GD45/12/220 Correspondence of the Earl and Countess of Panmure, 1716-1723.

${ }^{21}$ All in the NAS.

${ }^{22}$ Martyn Lyons (1999) Love Letters and Writing Practices: on ecritures intimes in the nineteenth century, Journal of Family History, 24, p. 237; Mireille Bossis and Karen McPherson (1986) Methodological journeys through correspondences, Yale French Studies, 71, p. 75 . 
${ }^{23}$ Clare Brant (2006) Eighteenth-Century Letters and British Culture (Houndmills: Palgrave Macmillan), p. 1.

${ }^{24}$ Bruce Redford (1986) The Converse of the Pen: acts of intimacy in the eighteenth century familiar letter (London: University of Chicago Press),

${ }^{25}$ Brant, Eighteenth-Century Letters, pp. 2-3.

${ }^{26}$ NAS GD158/2584/1-7 Hugh, Earl of Marchmont to Elizabeth Crompton, 1747; Brant, Eighteenth-Century Letters, p. 95.

${ }^{27}$ Barker-Benfield, Culture of Sensibility; Adela Pinch (1995) Emotion and history: a review, Comparative Studies in Society and History, 37, pp. 100-109; Rebecca Earle (2005) Letters and Love in Colonial Spanish America, The Americas, 62, p. 41.

${ }^{28}$ Her parents married in 1745, and pre-marital sex is unusual amongst this social group.

${ }^{29}$ Barclay, ‘Marital Relationships’, pp. 130-163.

${ }^{30}$ NAS GD248/370/5 James Grant to Jane Duff, 16 Nov 1762.

${ }^{31}$ Barclay, ‘Marital Relationships’, pp. 173-176.

${ }^{32}$ For a discussion of this trend see: Dwyer, Virtuous Discourse, pp. 95-116.

${ }^{33}$ NAS GD248/370/5 James Grant to Jane Duff, 26 Jan 1767.

${ }^{34}$ NAS GD248/370/5 James Grant to Jane Duff, 15 Aug 1773.

${ }^{35}$ For a discussion of language conventions, see Barclay, 'Marital Relationships', pp. 164205.

${ }^{36}$ NAS GD248/368/8 James Grant to Jane Duff, [c.1800].

${ }^{37}$ Earle, 'Letters and Love,’ p. 41.

${ }^{38}$ NAS GD461/126/3 Archibald Lawrie to Anne Adair, 6 Feb 1797.

39 See Katie Barclay (2008) Negotiating Patriarchy: the marriage of Anna Potts and Sir Archibald Grant of Monymusk, 1731-174, Journal of Scottish Historical Studies, 28, pp. 83101. 
${ }^{40}$ For a discussion of the relationship between Scottish and British identity amongst the Scottish elites see: Carr, ‘Gender, National Identity’, pp. 130-174.

${ }^{41}$ For rising conceptions of domesticity amongst the Scottish elites see: Dwyer, Virtuous Discourse, pp. 95-116; for the ways domesticity could give power to women see: Leonore Davidoff and Catherine Hall (1987) Family Fortunes: men and women of the English middle class, 1780-1850 (London: Chicago U.P.).

${ }^{42}$ Ruth Bernard Yeazell (1984) Fictions of Modesty: women and courtship in the English novel (Chicago: Chicago U.P.), p. 51; Nancy Cott (1978) Passionlessness: an interpretation of Victorian sexual ideology, 1790-1850, Signs, 4, pp. 219-236.

${ }^{43}$ NAS GD248/697/5 Jane Duff to James Grant.

${ }^{44}$ Barclay, 'Marital Relationships’, pp. 183-184.

45 NAS GD248/561/51/1 Elizabeth Hay to Lord Deskford, 21 Nov 1714; NAS GD112/39/107/4 Mary Campbell to Lord Breadalbane, 10 Sep [c. early 18thC].

46 This appears to be later than in England: Irene Brown (1982) Domesticity, Feminism and Friendship: female aristocratic culture and marriage in England, 1660-1760, Journal of Family History, 7, pp. 406-424.

${ }^{47}$ NAS GD248/518/2 Jane Duff to James Grant, 3 Apr 1799.

48 John Erskine of Carnock (1989 [1871]) An Institute of the Law of Scotland (Edinburgh: The Law Society of Scotland), pp. 152-158; George Bell (1839) Principles of the Law of Scotland (Edinburgh: Thomas Clark), p. 574. This reflected custom elsewhere, for example: Vickery, Gentleman’s Daughter, p. 64.

${ }^{49}$ NAS GD248/370/5 Anne Duff to ‘My Dear Sir’, [c. 1774].

${ }^{50}$ NAS GD18/5186/7 John Clerk to Elizabeth Clerk, [c.1690].

${ }^{51}$ NAS GD345/799/1 Francis Grant of Monymusk to Archibald Grant, [c. early $18^{\text {th }}$ Cent.]

${ }^{52}$ Stone, The Family, p. 210. 
53 In contrast, their husbands' age at marriage rose from 24.5 to 30, with a peak in the late eighteenth century of 31.9: Barclay, ‘Marital Relationships,’ pp. 120-126.

54 They have a factor, but she is occasionally directed on estate business.

${ }^{55}$ Barclay, 'Negotiating Patriarchy'.

${ }^{56}$ NAS GD248/518/2 James Duff to Jane Grant, [c.1764-70].

${ }^{57}$ For example, NAS GD248/198/2 James Grant to Jane Duff, 15 Oct 1783.

${ }^{58}$ NAS GD248/370/5 James Grant to Jane Duff, 9 Jun 1774.

${ }^{59}$ NAS GD248/515/2 James Grant to Jane Duff, [no date].

${ }^{60}$ For a discussion of ageing and chastity, see Laura Gowing (2003) Common Bodies: women, touch and power in seventeenth century England (London: Yale U.P.), pp. 77-81.

${ }^{61}$ Andrew Chricton (Ed.) (1924) Life and Diary of Col. John Blackadder (Edinburgh: H.S. Baynes), John Blackadder to Elizabeth Callander, 20 May 1705.

${ }^{62}$ For a discussion of couples who used the courts to separate and divorce see: Leah Leneman (1998) Alienated Affections: the Scottish experience of divorce and separation, 1684-1830 (Edinburgh: Edinburgh U.P.).

${ }^{63}$ NAS GD124/15/1372-1380 and /1506 and /1524- various letters of the Grange Family. 64 Dorothy McMillan (2004) Walker, Lady Mary (1736-1822), Oxford Dictionary of National Biography (Oxford: Oxford University Press)

[http://www.oxforddnb.com/view/article/12115, accessed 1 June 2009].

${ }^{65}$ GD124/15/1777/2 Philadelphia Stuart-Menteth to John Erskine, [Apr 1827].

${ }^{66}$ The change in his name reflected his new title, gained on his father's death in 1828.

${ }^{67}$ GD125/15/1790 Papers of John Miller, Alloa, concerning a conspiracy to carry off the Countess of Mar, 9 Dec 1831- 20 Jan 1832.

${ }^{68}$ GD124/15/1782 John Erskine to Philadelphia Stuart-Menteth, 29 Jan 1832

${ }^{69}$ GD124/15/1797 P. Miller to John Erskine, 31 Dec 1832. 
${ }^{70}$ GD124/15/1777/2 Philadelphia Stuart-Menteth to John Erskine, 19 Apr 1829

${ }^{71}$ For a discussion see: Robert Griswold (1986) The Evolution of the Doctrine of Mental Cruelty in Victorian American divorce, 1790-1900, Journal of Social History, 20, pp. 127148.

${ }^{72}$ For discussion, see: Pat Jalland (1986) Women, Marriage and Politics, 1860-1914 (Oxford: Oxford University Press), pp. 272-279.

${ }^{73}$ GD124/15/1782/7 John Erskine to Philadelphia Stuart-Menteth, 22 Mar 1829.

${ }^{74}$ GD124/15/1782/9 John Erskine to Philadelphia Stuart-Menteth, 9 Aug 1829.

${ }^{75}$ GD124/15/1782/20 John Erskine to Philadelphia Stuart-Menteth, 30 Apr 1832

${ }^{76}$ For a lengthy discussion of this see: Louise Carter (2008) British Masculinities on Trial in the Queen Caroline Affair of 1820, Gender and History, 20, pp. 248-269; Philip Carter (2001) Men and the Emergence of Polite Society, Britain 1660-1800 (Harlow: Routledge), p. 5. 